"Impact of audit committee characteristics on firm performance: Evidence from Bahrain"

\begin{tabular}{ll} 
AUTHORS & Abdulla Al-Jalahma (iD \\
\hline ARTICLE INFO & $\begin{array}{l}\text { Abdulla Al-Jalahma (2022). Impact of audit committee characteristics on firm } \\
\text { performance: Evidence from Bahrain. Problems and Perspectives in } \\
\text { Management, 20(1), 247-261. doi:10.21511/ppm.20(1).2022.21 }\end{array}$ \\
\hline DOI & http://dx.doi.org/10.21511/ppm.20(1).2022.21 \\
\hline RELEASED ON & Monday, 14 February 2022 \\
\hline RECEIVED ON & Thursday, 18 November 2021 \\
\hline ACCEPTED ON & Wednesday, 02 February 2022 \\
\hline LICENSE & $\begin{array}{l}(\text { (c) }) \text { EY } \\
\text { This work is licensed under a Creative Commons Attribution } 4.0 \text { International }\end{array}$ \\
\hline JOURNAL & License \\
\hline ISSN PRINT & "Problems and Perspectives in Management" \\
\hline ISSN ONLINE & $1727-7051$ \\
\hline PUBLISHER & $1810-5467$ \\
\hline FOUNDER & LLC "Consulting Publishing Company "Business Perspectives" \\
\hline
\end{tabular}

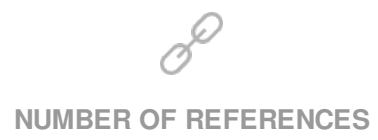

51

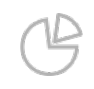

NUMBER OF FIGURES

0

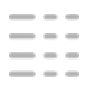

NUMBER OF TABLES

6

(C) The author(s) 2022. This publication is an open access article. 


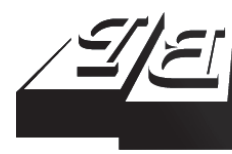

BUSINESS PERSPECTIVES

LLC "CPC "Business Perspectives" Hryhorii Skovoroda lane, 10, Sumy, 40022, Ukraine www.businessperspectives.org

Received on: $18^{\text {th }}$ of November, 2021 Accepted on: $2^{\text {nd }}$ of February, 2022 Published on: $14^{\text {th }}$ of February, 2022

(c) Abdulla Al-Jalahma, 2022

Abdulla Al-Jalahma, Ph.D., Assistant Professor, Department of Accounting, Faculty of Business Administration, University of Bahrain, Bahrain.
This is an Open Access article, distributed under the terms of the Creative Commons Attribution 4.0 International license, which permits unrestricted re-use, distribution, and reproduction in any medium, provided the original work is properly cited.

Conflict of interest statement: Author(s) reported no conflict of interest
Abdulla Al-Jalahma (Bahrain)

\section{IMPACT OF AUDIT COMMITTEE CHARACTERISTICS ON FIRM PERFORMANCE: EVIDENCE FROM BAHRAIN}

\begin{abstract}
The purpose of this study is to analyze the relationship between different audit committee attributes and company performance in Bahrain. This paper investigates the impact of audit committee independence, size, and meeting frequency on company performance (employing ROE, ROA, and Tobin's Q). Data from all 14 non-financial publicly listed companies on Bahrain Bourse during 2005-2019 were used. The results revealed that companies with independent audit committees and big audit committees in terms of size are performing poorly. It is also shown that the number of audit committee meetings does not affect company performance. Further, this study failed to find any association between the number of audit committee meetings and company performance. The findings show that shareholders might lack knowledge of the importance of corporate governance mechanisms. The results of this study should be of potential interest to different stakeholders, including regulators, investors, and auditors, in their attempts to improve company performance and monitoring mechanisms in emerging economies.
\end{abstract}

\section{Keywords}

corporate governance, independent directors, market performance, emerging markets

JEL Classification M41, M42, M48

\section{INTRODUCTION}

The interest in examining the relationship between corporate governance mechanisms and company's performance is escalating due to recent accounting scandals and corporate governance failures (Zhou et al., 2018). As a result, researchers and policy-makers have underlined the audit committee's oversight responsibilities as a critical element of any corporate governance system. In addition, there is a belief that audit committees should protect the interest of investors.

Based on agency theory, it is believed that a firm with a sound governance system will diminish agency costs and improve its performance and valuation. For instance, Gompers et al. (2003) state that firms with good corporate governance have a sound valuation. In addition, Brown and Caylor (2006) found that good corporate governance results in better performance (measured by return on assets, return on equity, and Tobin's Q). On the contrary, based on resource dependency theory, it is argued that firms might implement corporate governance mechanisms in order to have access to essential constituents, acquire support from outsiders, and gain legitimacy at an international level (Reitz, 1979). Therefore, from a resource dependency theory perspective, corporate governance mechanisms could negatively affect firm value and performance (Adams \& Ferreira, 2007; Khosa, 2017). Moreover, Montagna (1996) and Hopwood (2000) noted that different contextual factors might shape the association between corporate gov- 
ernance mechanisms and performance as socio-economic practices. Factors affecting these practices include business ownership, financing system, colonial inheritance, accounting profession, economic development, legal system, culture, history, geography, religion, language, political system, and social climate (Gray, 1988; Nobes \& Parker, 2010).

Prior studies have documented the influence of audit committees in increasing the quality of reported earnings and reducing internal control weakness (Klein, 2002). However, few studies investigated the audit committee's role in securing higher performance in emerging economies. Fan and Wong (2005) argued that corporate governance mechanisms, such as audit committees, may be insufficient to mitigate agency problems in emerging markets, especially between minority and controlling shareholders. In addition, concentrated ownership in emerging economies limits the monitoring mechanisms that might reduce agency conflicts (Jensen \& Meckling, 1976). Therefore, it is argued that audit committees might be used as a governance monitoring mechanism to reduce agency problems in emerging economies.

Prior literature investigates corporate governance from different aspects in developing markets; however, they neglect emerging markets, especially regarding the characteristics of audit committees. Several studies investigate the role of audit committees' characteristics in reducing earnings management (Klein, 2002) and weakening internal control systems (Zhang et al., 2007) in firms operating in developed countries. While audit committees' characteristics are well-research in developed countries, there is still a research gap in emerging markets like Bahrain. Thus, Bahrain provides an ideal condition to examine the association between firm performance and audit committee characteristics.

Next, the paper reviews the literature on the topic discussed and formulates the hypotheses. Then the research methodology used in this paper is explained, followed by the results and discussion. Finally, this paper summarizes, concludes, and suggests the potential findings for future research.

\section{LITERATURE REVIEW}

The agency conflict between shareholders and managers often causes managers to act in their best interests, against the shareholders' best interest (Jensen \& Meckling, 1976). Thus, it is crucial to have an environment containing monitoring tools and effective regulations to protect the shareholders' interests (Turley \& Zaman, 2014). Furthermore, it is essential to have effective and successful corporate governance practices (e.g., audit committee) to mitigate such conflicts (Krishnan, 2005). Kallamu and Saat (2015) investigated the correlation between audit committee characteristics and performance and found mixed results. This study aims to analyze the relationship between audit committees' characteristics (which include audit committee independence, size, and frequency of meetings) and firm performance.

Agency theory indicates that independent directors offer efficient monitoring tools for the management. These tools can decrease opportunistic behaviors among managers and enhance company performance. Independent audit committee members do their duties by assessing the financial reporting and providing good audit quality (Peasnell et al., 2005). Kallamu and Saat (2015), investigating the independent audit committee, provided inconclusive findings. Although Bolton (2014) and Bansal and Sharma (2016) noted that there is no significant association between audit committee independence and company performance, other studies found that such independence is significantly related to performance (Chan \& Li, 2008). Yameen and Tabash (2019), Ben Barka and Legendre (2017), Nawafly et al. (2018), and Oroud (2019) discovered that the independence of audit committee is positively related to firm performance. In addition, using Tobin's Q, Dakhlallh et al. (2020) found that the independence of the audit committee is positively associated with the performance of listed companies in Jordan. Aanu et al. (2014) also noted a positive association between audit committee independence and performance in Nigerian companies. 
Moreover, Kaura et al. (2019) claim that the independence of the audit committee is positively and significantly related to firm performance. It was found that ROA and ROE are positively related to the independence of audit committees in Indian listed IT companies. Controversially, this relationship was found to be negative for other contexts. For instance, Almoneef and Samontaray (2019) noted a negative relationship for listed banks in Saudi Arabia. Moreover, Sarpal (2017) noted that the independence of audit committees is negatively related to performance in Indonesia and India.

Meetings of the audit committee, which measure their effectiveness, are considered one of the essential elements of reviewing the financial reporting process of any company. Prior studies investigating the relationships between audit committee meetings and company performance have inclusive findings (Aldamen et al., 2012). For example, Al Farooque et al. (2020) found that the frequency of audit committee meetings for Thai companies is significantly and positively related to the firm performance. In addition, the number of audit committee meetings was also found to be significantly and positively related to the performance of Saudi banks (Almoneef \& Samontaray, 2019). Moreover, this construct was significantly positively related to the performance of banks in Indonesia (Chou \& Buchdadi, 2017) and companies in Jordan (Oroud, 2019). However, this relationship was negative for other contexts (Vafeas, 1999).

Rahman et al. (2019) found that the additional cost incurred for holding audit committee meetings negatively affects this relationship. On the contrary, Bansal and Sharma (2016) noted an insignificant relationship between audit committee meetings and firm performance. Furthermore, Alqatamin (2018) claimed that the meetings number is insignificantly related to the performance of non-financial Jordanian listed companies. Moreover, Al-Matari et al. (2014) discovered that the number of meetings is insignificantly related to company performance for Omani companies.

The audit committee size is an essential element that supports the committee's success. The number of committee members assists in overcom- ing issues of the companies reporting ( $\mathrm{Li}$ et al., 2012). Therefore, it is assumed that the quality of financial reports is affected by the size of the audit committee. However, the findings from prior studies on the association between the size of the audit committee and firm performance are inconclusive (Rahmat et al., 2009). For example, Herdjiono and Sari (2017), Aanu et al. (2014), and Oroud (2019) found an insignificant relationship between firm performance and audit committee size in Indonesian, Nigerian, and Jordanian companies, respectively. Ghabayen (2012) also found no relationship for Saudi companies. However, this relationship was positively significant for Jordanian banks (Warrad \& Khaddam, 2020). In addition, the size of the audit committee was positively related to the performance of UK listed companies (Al-Okaily \& Naueihed, 2020) and Omani non-financial listed companies (Al-Matari et al., 2014). Moreover, Sarpal (2017) showed that the audit committee size is positively correlated with firm value for Indian companies. On the other hand, Afza and Nazir (2014) state that the committee size is negatively and significantly associated with firm performance in Pakistan. Kipkoech and Rono (2016) also found the same association for Kenyan companies.

Given the mixed results reported by the literature review on the association between audit committee characteristics and company performance in various contexts and the study objectives, the study suggests the following hypotheses. They test the relationship between audit committee characteristics, namely, independence, size, number of meetings, and company performance.

Study hypotheses are as follows:

H1: There is a significant relationship between audit committee independence and company performance.

H2: There is a significant relationship between audit committee meetings and company performance.

H3: There is a significant relationship between audit committee size and company performance. 


\section{AIMS}

The paper aims to analyze the influence of audit committee characteristics on the performance of Bahraini non-financial listed companies. The study investigated the influence of (i) audit committee independence, (ii) audit committee size, and (iii) frequency of audit committee meetings on firm performance by developing three regression models. In these models, return on assets (ROA) and return on equity (ROE) were used as indicators for measuring the profitability of companies, and Tobin's Q was used to evaluate the companies' market values and book values.

\section{METHODOLOGY}

\subsection{Data collection}

The study comprises all Bahraini listed companies (the entire population) (see Table A1, Appendix A) for a period spanning the introduction of the 2011 Code on Corporate Governance. The study covers the financial years from December 2005 to December 2019 (before the COVID-19 pandemic). The implementation of the Code on Corporate Governance started in December 2011. The sample is restricted to non-financial companies since financial and insurance firms must follow specific accounting and regulatory requirements that differ substantially from non-financial companies. In addition, they have specific practices and operations. The financial data for all companies are taken from the Datastream database. In addition, information on corporate governance and missing financial data were manually collected from annual reports.

After the exclusions mentioned above, the final sample consists of 214 firm-year observations from 2005 to 2019. The whole sample's firm performance is measured using three different measures (ROA, ROE, and TQ). However, variable numbers of the initial firm-year observations had insufficient data to estimate the influence of audit committee characteristics on the performance as the corporate governance disclosure became mandatory in 2011. This leaves a final sample of 125 firm-year observations to capture the role of the audit committee independence; 125 firm-year observations to capture the role of the audit committee size; 125 firm-year observations to capture the role of the audit committee meeting. In order to investigate the association between various audit committee characteristics and company performance, the following empirical models are formulated:

$$
\begin{aligned}
& T Q=\beta_{0}+\beta_{1} A C I N D+\beta_{2} A C S I Z E+ \\
& +\beta_{3} A C M E E T+L E V+S I Z E+\varepsilon_{t} . \\
& R O A=\beta_{0}+\beta_{1} A C I N D+\beta_{2} A C S I Z E+ \\
& +\beta_{3} A C M E E T+L E V+S I Z E+\varepsilon_{t} . \\
& R O E=\beta_{0}+\beta_{1} A C I N D+\beta_{2} A C S I Z E+ \\
& +\beta_{3} A C M E E T+L E V+S I Z E+\varepsilon_{t} .
\end{aligned}
$$

Definitions and measurements are provided in Tables 1 and 2 for all variables.

\subsection{Measurement of variables}

\subsubsection{Dependent variables}

The paper analyzes the influence of audit committee characteristics on different types of firm performance, including financial, operational, and market performance. Following prior studies, this study measures company performance using three different proxies: ROA, ROE, and Tobin's Q. These measures show the profitability of any investment and reflect the company's ability to generate returns on its portfolio of assets. They also considered the changes in the equity market. These measures are widely used in corporate governance studies since they reflect the management's ability to utilize its resources (Al-Okaily \& Naueihed, 2020; Alqatamin, 2018; Brick \& Chidambaran, 2010; Chan \& Li, 2008; Zhang et al., 2007). Table 1 shows the description of three dependent variables (performance measures).

Table 1. Dependent variables

\begin{tabular}{l:l}
\hline $\begin{array}{c}\text { Dependent } \\
\text { variables }\end{array}$ & \multicolumn{1}{c}{ Descriptions } \\
\hline TQ & It is equal to the (Market value of equity + Book \\
& value of debt) $\div$ Book value of total assets \\
ROA & It is equal to the net income (EBIT) divided by the \\
& total assets at the beginning of the year \\
ROE & $\begin{array}{l}\text { It is equal to the net income (EBIT) divided by the } \\
\text { total equity at the beginning of the year }\end{array}$ \\
\hline
\end{tabular}




\subsubsection{Independent and control variables}

The independent variables and their measurement used in this study are summarized in Table 2. The independent variables are derived from the literature. For example, three variables representing the audit committee attributes are audit committee independence, audit committee size, and the number of audit committee meetings.

In addition to the independent variables, two controlling variables are used in the three models implemented in this study. They monitor firm characteristics that can affect firm performance and ensure that the statistical tests focus more on the differences created by variations in corporate governance mechanisms. These variables contain firm size and leverage. Prior studies have presented evidence that large firms might perform better than small firms because they have more resources. Previous studies use leverage to measure debt covenant violations and represent the firm's debt structure. Most studies found that leverage is positively related to wrongdoings like manipulating firm performance (Elayan et al., 2008). However, some studies claimed leverage negatively related to earnings management (Becker et al., 1998).
This study does not include other common control variables, such as industry. The reason for excluding these variables is that the sample under investigation is small; a considerable number of variables will lower the model's explanatory power (small degree of freedom).

\section{RESULTS AND DISCUSSION}

\subsection{Descriptive statistics}

Table 3 shows the descriptive statistics for each variable in the sample dataset, namely the mean, standard deviation, minimum, and maximum of all variables.

Table 3 shows a significant range of variation between the samples of the study. The range of AC Independence is from $0 \%$ to $100 \%$ and has a standard deviation of 35.135 . The AC Size ranges from 0 to 6 members with a mean of 4 members. The AC Meeting ranges from 0 meetings to 8 meetings with a mean of 4 meetings per year. The Size ranges from $9,356,517$ to $1,567,224$ with an average of 1,173,132. The LEV ranges from 1 to 3.01 with a mean of 1.336 . The ROA ranges from -0.15487 to 0.4186 with an average of 0.0807 and a standard deviation of 0.0685 . The ROE rang-

Table 2. Descriptions of explanatory and control variables

\begin{tabular}{|c|c|}
\hline Variables & Descriptions \\
\hline \multicolumn{2}{|r|}{ Independent variables } \\
\hline Audit committee independence & $\begin{array}{l}\text { Equal to the ratio of independent (non-executive) directors in the audit committee to total committee } \\
\text { members. Members are independent if their tenure as a board member does not exceed five years, } \\
\text { they are not ex-employees of the firm or related to senior management, they are not consultants, } \\
\text { lawyers, or financial advisors, and they are not engaged in a reciprocal interlock }\end{array}$ \\
\hline Audit committee size & Equal the number of members in the audit committee \\
\hline Audit committee meetings & Equal the number of meetings per year held by the audit committee \\
\hline \multicolumn{2}{|r|}{ Control variables } \\
\hline Firm size & Equal the natural logarithm of total assets at year-end \\
\hline Leverage & Equal total debt divided by total assets \\
\hline
\end{tabular}

Table 3. Descriptive statistics

\begin{tabular}{|c|c|c|c|c|}
\hline Variable & Mean & Std. Dev. & Min & Max \\
\hline ROA & 0.080738 & 0.068518 & -0.15487 & 0.4186 \\
\hline ROE & 0.104474 & 0.09057 & -0.29369 & 0.465424 \\
\hline $\mathrm{TQ}$ & 860.5034 & 490.1528 & 107.178 & 2765.061 \\
\hline Audit Committee Independence & 37.45802 & 35.13518 & 0 & 100 \\
\hline Audit Committee Size & 3.613793 & 0.906659 & 0 & 6 \\
\hline Audit Committee Meetings & 4.398374 & 1.15048 & 0 & 8 \\
\hline SIZE & $1,173,132$ & $1,340,519$ & $9,356,517$ & $1,567,224$ \\
\hline LEV & 1.33688 & 0.375491 & 1.007797 & 3.013845 \\
\hline
\end{tabular}


es from -0.29369 to 0.465424 with an average of 0.1044 and a standard deviation of 0.0905 . The TQ ranges from 107.178 to 2765.061 with an average of 0.104474 and a standard deviation of 0.09057 .

\subsection{Multicollinearity}

It is crucial to test the relationship between dependent and independent variables by preparing an analysis of correlation coefficients (Rahman \& Mohamed Ali, 2006). Therefore, Table 4 presents the correlation coefficient that checks for high collinearity between variables employing the Pearson test. The correlations show no multicollinearity as none of the variables correlate above 0.3 . Gujarati (2004) and Rahman and Mohamed Ali (2006) suggest that the value of 0.9 is not multicollinearity and it will not harm the regression analysis.

\subsection{Regression analysis}

The three models aim to analyze the association between audit committee characteristics and firm performance. The ROE model has an R2 value of
$33.09 \%$, the ROA model has an $\mathrm{R} 2$ value of $25.46 \%$, and the TQ model has an R2 value of $36.71 \%$. The power for the three models is not low compared to other studies; for instance, the adjusted R2, according to Rahman and Mohamed Ali (2006), is $12.8 \%$. However, Rahmat et al. (2009) stated that low R2 values in similar studies that examine corporate governance characteristics are common.

The study hypothesizes a significant relationship between the audit committee characteristics and company performance. Based on the study findings, we accept two hypotheses which are: there is a significant relationship between audit committee independence and company performance and there is a significant relationship between audit committee meetings and company performance. However, we reject the third hypothesis which is: there is a significant relationship between audit committee size and company performance.

Table 5 showed that the audit committee independence had negative signs in all the three models but was significant at a $1 \%$ level of significance.

Table 4. Correlation matrix

\begin{tabular}{|c|c|c|c|c|c|c|c|c|}
\hline & ROE & ROA & TQ & ACIND & ACSIZE & ACMEET & SIZE & LEV \\
\hline ROE & 1 & & & & & & & \\
\hline ROA & $0.938^{* * *}$ & 1 & & & & & & \\
\hline TQ & $0.507^{* * *}$ & $0.586^{* * *}$ & 1 & & & & & \\
\hline ACIND & -0.0876 & -0.126 & $-0.297^{* * *}$ & 1 & & & & \\
\hline ACSIZE & -0.0223 & -0.00900 & -0.111 & 0.0538 & 1 & & & \\
\hline ACMEET & 0.0489 & -0.0518 & $-0.235^{* * *}$ & $0.306^{* * *}$ & -0.0174 & 1 & & \\
\hline SIZE & $0.323^{* * *}$ & $0.198^{* * *}$ & -0.00727 & $0.316^{* * *}$ & $0.437^{* * *}$ & $0.234^{* * *}$ & 1 & \\
\hline LEV & 0.0683 & $-0.128^{*}$ & $-0.316^{* * *}$ & 0.121 & 0.0821 & $0.328^{* * *}$ & $0.521^{* * *}$ & 1 \\
\hline $\mathrm{N}$ & 230 & & & & & & & \\
\hline
\end{tabular}

Note: ${ }^{*} p<0.10,{ }^{* *} p<0.05,{ }^{* * *} p<0.01$.

Table 5. Regression results in terms of different models

\begin{tabular}{|c|c|c|c|}
\hline \multirow{2}{*}{ Variables } & (1) & (2) & (3) \\
\hline & ROE & ROA & TQ \\
\hline \multirow{2}{*}{ ACIND } & $-0.000643^{* * *}$ & $-0.000461^{* * *}$ & $-5.059^{* * *}$ \\
\hline & $(-3.28)$ & $(-2.82)$ & $(-4.57)$ \\
\hline \multirow{2}{*}{ ACSIZE } & $-0.0246^{* * *}$ & $-0.0148^{* *}$ & $-142.3^{* * *}$ \\
\hline & $(-2.91)$ & $(-2.10)$ & $(-2.99)$ \\
\hline \multirow{2}{*}{ ACMEET } & 0.00985 & 0.00310 & -25.58 \\
\hline & $(1.56)$ & $(0.59)$ & $(-0.72)$ \\
\hline \multirow{2}{*}{ SIZE } & $0.0421^{* * *}$ & $0.0259^{* * *}$ & $137.9^{* * *}$ \\
\hline & $(6.96)$ & $(5.16)$ & $(4.05)$ \\
\hline \multirow{2}{*}{ LEV } & $-0.105^{* * *}$ & $-0.0835^{* * *}$ & $-647.3^{* * *}$ \\
\hline & $(-5.45)$ & $(-5.20)$ & $(-5.94)$ \\
\hline \multirow{2}{*}{ _cons } & $-0.200^{* * *}$ & -0.0685 & $867.0^{* * *}$ \\
\hline & $(-3.55)$ & $(-1.46)$ & $(2.73)$ \\
\hline N & 125 & 125 & 125 \\
\hline R2 & 0.3309 & 0.2546 & 0.3671 \\
\hline
\end{tabular}

Note: $t$-statistics is in parentheses. ${ }^{*} p<0.10,{ }^{* *} p<0.05,{ }^{* * *} p<0.01$. 
These results are not in line with the agency and resource dependence theories and are not supported by the majority of prior research. Previous studies have shown that audit committee independence is positively related to firm performance (Yameen et al., 2019; Ben Barka \& Legendre, 2017).

However, the finding is consistent with Bolton (2014), who showed no significant relationship between firm performance and the independence of the audit committee. Furthermore, the finding of independent outsiders represents the Bahraini context. The majority of independent members in Bahrain serve for many years on the same board, which influences their independence as they build some relationships with the executive management. Therefore, the outsider might not affect the firm performance positively anymore.

Results in Table 5 showed that the audit committee size had negative signs in all three models but was significant. Again, these findings do not support the agency and resource dependence theories. Prior research has shown that audit committee size is positively related to firm performance (Warrad \& Khaddam, 2020; Al-Okaily \& Naueihed, 2020). However, this finding is consistent with Herdjiono and Sari (2017), who found no significant relationship.

Inconsistent with the theoretical assumption, Table 5 shows that the number of audit commit- tee meetings is not significantly related to firm performance in all three models. The finding is inconsistent with previous studies that found a significant relationship between the number of audit committee meetings and firm performance (Al Farooque et al., 2020). However, for example, Alqatamin (2018) could not find evidence that the frequency of audit committee meetings has a relationship with firm performance. A possible explanation for this finding is that the number of meetings does not directly impact the committee's effectiveness in limiting the agency cost.

The study expects that other factors could affect firm performance. Therefore, the regression models included two control variables. The findings show that company size is positively and significantly related to company performance, which is consistent with prior studies. For example, Warrad and Khaddam (2020) found that company size improves its performance as the company will have more assets to invest and have more opportunities to access external funds at a low cost than smaller companies, which can increase the company value. On the other hand, the study finds that company performance is negatively and significantly related to leverage. The results are consistent with Campbell and Mínguez-Vera (2008), who found that a high level of leverage will limit the number of resources available for investment as they have to meet the debt covenant.

\section{CONCLUSION}

This study examined the impact of audit committee characteristics on firm performance, investigating the effects of audit committee independence, audit committee size, and audit committee meetings on the performance of Bahraini non-financial listed companies. The study employs data from non-financial (14) companies listed in Bahrain Bourse from 2005 to 2019. The findings showed that the independence of the audit committee and its size are negatively related to company performance. However, the paper has also shown that the number of audit committee meetings is not affecting the firm performance as there is no significant association.

The findings show that shareholders, board of directors, and audit committee members might lack knowledge of the importance of corporate governance mechanisms. Therefore, regulators should enhance the awareness of the importance of these mechanisms between different stakeholders and directors. In addition, the findings show that companies might adopt practices or regulations to improve organizational effectiveness as a result of coercion or imposition from a legislator. The results of this study can be used to amend existing rules and regulations to provide a more effective regulatory system that will increase investor and stakeholder protection. In addition, they can be used to improve the Bahraini governance system, including the Code on Corporate Governance that was introduced in 2011. 
This paper shows that the efficiency of these practices and monitoring mechanisms differ from one context to another. In addition, the study was limited by the coverage of non-financial listed companies in Bahrain. It also excluded financial and insurance companies. Therefore, the findings of this study cannot be generalized to all sectors of the Bahraini market. Moreover, additional independent variables can be considered in the future, such as audit variables (e.g., specialist auditors, non-audit fees, and auditor fees); however, the unavailability of necessary data has prevented this study from including them.

Future studies should investigate this relationship between non-financial listed companies and financial listed companies as they all contribute to the economy. In addition, further research should analyze the relationship between corporate governance mechanisms and firm performance in different contexts and use a qualitative research approach, such as interviews, to understand this issue deeper. It will provide more evidence on the role of corporate governance mechanisms as monitoring tools from different economies, showing the effect of the institutional setting (contextual factors).

\section{AUTHOR CONTRIBUTIONS}

Conceptualization: Abdulla Al-Jalahma.

Data curation: Abdulla Al-Jalahma.

Formal analysis: Abdulla Al-Jalahma.

Investigation: Abdulla Al-Jalahma.

Methodology: Abdulla Al-Jalahma.

Project administration: Abdulla Al-Jalahma.

Supervision: Abdulla Al-Jalahma.

Validation: Abdulla Al-Jalahma.

Visualization: Abdulla Al-Jalahma.

Writing - original draft: Abdulla Al-Jalahma.

Writing - review \& editing: Abdulla Al-Jalahma.

\section{REFERENCES}

1. Aanu, O. S., Iyoha, F. O., \& Obigbemi, I. F. (2014). Effectiveness of audit committee and firm financial performance in Nigeria: an empirical analysis. Journal of Accounting and Auditing: Research \& Practice. https://doi. org/10.5171/2014.301176

2. Adams, R. B., \& Ferreira, D. (2007). A theory of friendly boards. Journal of Finance, 62(1), 217-250. https://doi.org/10.1111/j.15406261.2007.01206.x

3. Afza, T., \& Nazir, M. S. (2014). Audit quality and firm value: A case of Pakistan. Research Journal of Applied Sciences, Engineering and Technology, 7(9), 1803-1810. https://doi.org/10.19026/rjaset.7.465

4. Al Farooque, O., Buachoom, W., \& Sun, L. (2020). Board, audit committee, ownership and financial performance - emerging trends from Thailand. Pacific Accounting Review, 32(1), 54-81. https://doi.org/10.1108/PAR-102018-0079

5. Aldamen, H., Duncan, K., Kelly, S., Mcnamara, R., \& Nagel, S. (2012). Audit committee characteristics and firm performance during the global financial crisis. Accounting and Finance, 52(4), 971-1000. https://doi.org/10.1111/j.1467629X.2011.00447.x

6. Al-Matari, E. M., Al-Swidi, A. K., \& Fadzil, F. H. B. (2014). Audit committee characteristics and executive committee characteristics and firm performance in Oman: Empirical study. Asian Social Science, 10(12), 98-113. https://doi.org/10.5539/ ass.v10n12p98

7. Almoneef, A., \& Samontaray, D. P. (2019). Corporate governance and firm performance in the Saudi banking industry. Banks and Bank Systems, 14(1), 147158. https://doi.org/10.21511/ bbs.14(1).2019.13

8. Al-Okaily, J., \& Naueihed, S. (2020). Audit committee effectiveness and family firms: impact on performance. Management Decision, 58(6), 1021-1034. https://doi. org/10.1108/MD-04-2018-0422

9. Alqatamin, R. M. (2018). Audit Committee Effectiveness and Company Performance: Evidence from Jordan. Accounting and Finance Research, 7(2), 48-60. https://doi.org/10.5430/afr. v7n2p48

10. Bansal, N., \& Sharma, A. K. (2016). Audit Committee, Corporate Governance and Firm Performance: Empirical Evidence 
from India. International Journal of Economics and Finance, 8(3), 103-116. https://doi.org/10.5539/ ijef.v8n3p103

11. Becker, C. L., Defond, M. L., Jiambalvo, J., \& Subramanyam, K. R. (1998). The Effect of Audit Quality on Earnings Management. Contemporary Accounting Research, 15(1), 1-24. https://doi. org/10.1111/J.1911-3846.1998. TB00547.X

12. Ben Barka, H., \& Legendre, F. (2017). Effect of the board of directors and the audit committee on firm performance: a panel data analysis. Journal of Management and Governance, 21(3), 737-755. https://doi.org/10.1007/s10997016-9356-2

13. Bolton, B. (2014). Audit committee performance: Ownership vs.independence Did SOX get it wrong? Accounting and Finance, 54(1), 83-112. https://doi.org/10.1111/j.1467629X.2012.00504.x

14. Brick, I. E., \& Chidambaran, N. K. (2010). Board meetings, committee structure, and firm value. Journal of Corporate Finance, 16(4), 533-553. https://doi. org/10.1016/j.jcorpfin.2010.06.003

15. Brown, L. D., \& Caylor, M. L. (2006). Corporate governance and firm valuation. Journal of Accounting and Public Policy, 25(4), 409-434. https://doi.org/10.1016/j. jaccpubpol.2006.05.005

16. Campbell, K., \& Mínguez-Vera, A. (2008). Gender Diversity in the Boardroom and Firm Financial Performance. Journal of Business Ethics, 83(3), 435-451. https://doi org/10.1007/S10551-007-9630-Y

17. Chan, K. C., \& Li, J. (2008). Audit committee and firm value: Evidence on outside top executives as expert-independent directors. Corporate Governance: An International Review, 16(1), 1631. https://doi.org/10.1111/j.14678683.2008.00662.x

18. Chou, T.-K., \& Buchdadi, A. D. (2017). Independent Board, Audit Committee, Risk Committee, the Meeting Attendance level and Its Impact on the Performance:
A Study of Listed Banks in Indonesia. International Journal of Business Administration, 8(3), 24-36. https://doi.org/10.5430/ijba. v8n3p24

19. Dakhlallh, M. M., Rashid, N., Wan Abdullah, W. A., \& Al Shehab, H. J. (2020). Audit committee and Tobin's $\mathrm{Q}$ as a measure of firm performance among Jordanian companies. Journal of Advanced Research in Dynamical and Control Systems, 12(1), 28-41. https://doi.org/10.5373/JARDCS/ V12I1/20201005

20. Elayan, F. A., Li, J., \& Meyer, T. O. (2008). Accounting irregularities, management compensation structure and information asymmetry. Accounting \& Finance, 48(5), 741-760. https:// doi.org/10.1111/J.1467629X.2008.00266.X

21. Fan, J. P. H., \& Wong, T. J. (2005). Do External Auditors Perform a Corporate Governance Role in Emerging Markets? Evidence from East Asia. Journal of Accounting Research, 43(1), 35-72. https://doi.org/10.1111/J.1475679X.2004.00162.X

22. Ghabayen, M. A. (2012). Board Characteristics and Firm Performance: Case of Saudi Arabia. International Journal of Accounting and Financial Reporting, 2(2). https://doi. org/10.5296/ijafr.v2i2.2145

23. Gompers, P., Ishii, J., \& Metrick, A. (2003). Corporate governance and equity prices. The Quarterly Journal of Economics, 118(1), 107-156. https://doi org/10.1162/00335530360535162

24. Gray, S. J. (1988). Towards a Theory of Cultural Influence on the Development of Accounting Systems Internationally. Abacus, 24(1), 1-15. https://doi. org/10.1111/J.1467-6281.1988. TB00200.X

25. Gujarati, D. N. (2004). Basic Econometrics (5 ${ }^{\text {th }}$ ed.). McGawHill.

26. Herdjiono, I., \& Sari, I. M. (2017). The effect of corporate governance on the performance of a company. Some empirical findings from
Indonesia. Central European

Management Journal, 25(1), 33-52.

https://doi.org/10.7206/jmba.

ce.2450-7814.188

27. Hopwood, A. G. (2000).

Understanding financial accounting practice. Accounting Organizations and Society, 25(8), 763-766. https://doi.org/10.1016/ S0361-3682(00)00021-0

28. Jensen, M. C., \& Meckling, W. H. (1976). Theory of the firm: Managerial behavior, agency costs and ownership structure. Journal of Financial Economics, 3(4), 305360. https://doi.org/10.1016/0304405X(76)90026-X

29. Kallamu, B. S., \& Saat, N. A. M. (2015). Audit committee attributes and firm performance: evidence from Malaysian finance companies. Asian Review of Accounting, 23(3), 206-231. https:// doi.org/10.1108/ARA-11-20130076

30. Kaura, P., Dharwal, M., Kaur, H., \& Kaur, P. (2019). Impact of corporate governance on financial performance of information technology companies. International Journal of Recent Technology and Engineering, 8(3), 7460-7464. https://doi. org/10.35940/ijrte.C5603.098319

31. Khosa, A. (2017). Independent directors and firm value of groupaffiliated firms. International Journal of Accounting \& Information Management, 25(2), 217-236. https://doi.org/10.1108/ IJAIM-08-2016-0076

32. Kipkoech, S. R., \& Rono, L. (2016). Audit Committee Size, Experience and Firm Financial Performance. Evidence Nairobi Securities Exchange, Kenya. Research Journal of Finance and Accounting, 7(15), 87-95. Retrieved from https://iiste. org/Journals/index.php/RJFA/ article/view/32732

33. Klein, A. (2002). Audit committee, board of director characteristics, and earnings management. Journal of Accounting and Economics, 33(3), 375-400. https://doi.org/10.1016/S01654101(02)00059-9

34. Krishnan, J. (2005). Audit committee quality and internal 
control: An empirical analysis. Accounting Review, 80(2), 649675. https://doi.org/10.2308/ accr.2005.80.2.649

35. Li, J., Mangena, M., \& Pike, R. (2012). The effect of audit committee characteristics on intellectual capital disclosure. British Accounting Review, 44(2), 98-110. https://doi.org/10.1016/j. bar.2012.03.003

36. Montagna, P. (1996). Review of Accounting as Social and Institutional Practice., by A. G. Hopwood \& P. Miller. Contemporary Sociology, 25(1), 103-104. https://doi. org/10.2307/2076997

37. Nawafly, A. T. M., \& Alarussi, A. S. A. (2018). Board of directors, audit committee and the financial performance of listed companies in Malaysia. Journal of Social Sciences Research, 2018(Special Issue 6), 951-957. https://doi. org/10.32861/jssr.spi6.951.957

38. Nobes, C., \& Parker, R. (2010). Comparative International Accounting. Prentice Hall.

39. Oroud, Y. (2019). The Effect of Audit Committee Characteristics on the Profitability: Panel Data Evidence. International Journal of Economics and Finance, 11(4), 104-113. https://doi.org/10.5539/ ijef.v11n4p104

40. Peasnell, K. V., Pope, P. F., \& Young, S. (2005). Board Monitoring and Earnings Management: Do Outside Directors Influence Abnormal Accruals? Journal of Business Finance \& Accounting, 32(78), 1311-1346. https://
doi.org/10.1111/J.0306-

686X.2005.00630.X

41. Rahman, M. M., Meah, M. R., \& Chaudhory, N. U. (2019). The impact of audit characteristics on firm performance: An empirical study from an emerging economy. Journal of Asian Finance, Economics and Business, 6(1), 59-69. https://doi.org/10.13106/ jafeb.2019.vol6.no1.59

42. Rahman, R. A., \& Mohamed Ali, F. H. (2006). Board, audit committee, culture and earnings management: Malaysian evidence. Managerial Auditing Journal, 21(7), 783-804. https://doi. org/10.1108/02686900610680549

43. Rahmat, M., Iskandar, T., \& Saleh, N. (2009). Audit committee characteristics in financially distressed and non-distressed companies. Managerial Auditing Journal, 2(7), 624-638. Retrieved from https://ideas.repec.org/a/ eme/majpps/v24y2009i7p624-638. html

44. Reitz, H. J. (1979). Review of The External Control of Organizations: A Resource Dependence Perspective, by J. Pfeffer \& G. R. Salancik. The Academy of Management Review, 4(2), 309-310. https://doi. org/10.2307/257794

45. Sarpal, S. (2017). Analyzing Performance Implications of Selected Audit Committee Characteristics: A Study of Indian Corporate Sector. Business Perspectives and Research, 5(2), 137-150. Retrieved from https:// ideas.repec.org/a/sae/busper/ v5y2017i2p137-150.html
46. Turley, S., \& Zaman, M. (2014). The Corporate Governance Effects of Audit Committee. In R. Di Pietra, S. McLeay, \& J. Ronen (Eds.), Accounting and Regulation (pp. 133-159). Springer. https://doi. org/10.1007/978-1-4614-8097-6_7

47. Vafeas, N. (1999). Board meeting frequency and firm performance. Journal of Financial Economics, 53(1), 113-142. https://doi.org/10.1016/S0304405X(99)00018-5

48. Warrad, L., \& Khaddam, L (2020). The effect of corporate governance characteristics on the performance of Jordanian banks. Accounting, 6(2), 117-126. https:// doi.org/10.5267/j.ac.2019.12.001

49. Yameen, M., \& Tabash, M. I. (2019). The impact of corporate governance practices on firm's performance: An empirical evidence from Indian tourism sector. Journal of International Studies, 12(1), 208-228. https://doi. org/10.14254/2071-8330.2019/12$1 / 14$

50. Zhang, Y., Zhou, J., \& Zhou, N. (2007). Audit committee quality, auditor independence, and internal control weaknesses. Journal of Accounting and Public Policy, 26(3), 300-327. https:// doi.org/10.1016/J.JACCPUBPOL.2007.03.001

51. Zhou, H., Owusu-Ansah, S., \& Maggina, A. (2018). Board of directors, audit committee, and firm performance: Evidence from Greece. Journal of International Accounting, Auditing and Taxation, 31, 20-36. https://doi.org/10.1016/j. intaccaudtax.2018.03.002 
APPENDIX A

Table A1. List of all Bahraini non-financial listed companies covered by the study

\begin{tabular}{|c|c|c|c|c|}
\hline Company & Industry & Year & Total Assets (\$ million) & Total Shareholders' Equity (\$ million) \\
\hline NASS CORPORATION BSC & Construct. \& Material & 2005 & 146,236 & 75,260 \\
\hline NASS CORPORATION BSC & Construct. \& Material & 2006 & 149,647 & 76,024 \\
\hline NASS CORPORATION BSC & Construct. \& Material & 2007 & 176,160 & 86,699 \\
\hline NASS CORPORATION BSC & Construct. \& Material & 2008 & 270,039 & 103,776 \\
\hline NASS CORPORATION BSC & Construct. \& Material & 2009 & 266,585 & 132,383 \\
\hline NASS CORPORATION BSC & Construct. \& Material & 2010 & 271,526 & 139,698 \\
\hline NASS CORPORATION BSC & Construct. \& Material & 2011 & 263,590 & 143,074 \\
\hline NASS CORPORATION BSC & Construct. \& Material & 2012 & 311,472 & 145,064 \\
\hline NASS CORPORATION BSC & Construct. \& Material & 2013 & 262,537 & 147,418 \\
\hline NASS CORPORATION BSC & Construct. \& Material & 2014 & 265,408 & 149,700 \\
\hline NASS CORPORATION BSC & Construct. \& Material & 2015 & 292,691 & 148,056 \\
\hline NASS CORPORATION BSC & Construct. \& Material & 2016 & 341,545 & 153,407 \\
\hline NASS CORPORATION BSC & Construct. \& Material & 2017 & 417,897 & 166,624 \\
\hline NASS CORPORATION BSC & Construct. \& Material & 2018 & 419,653 & 170,220 \\
\hline NASS CORPORATION BSC & Construct. \& Material & 2019 & 441,257 & 156,183 \\
\hline BAHRAIN TELECOMMUNICATION COMPANY & Telecommunications & 2005 & $1,052,437$ & 890,102 \\
\hline BAHRAIN TELECOMMUNICATION COMPANY & Telecommunications & 2006 & $1,276,329$ & 961,976 \\
\hline BAHRAIN TELECOMMUNICATION COMPANY & Telecommunications & 2007 & $1,948,785$ & $1,078,606$ \\
\hline BAHRAIN TELECOMMUNICATION COMPANY & Telecommunications & 2008 & $1,895,918$ & $1,199,171$ \\
\hline BAHRAIN TELECOMMUNICATION COMPANY & Telecommunications & 2009 & $1,785,358$ & $1,308,557$ \\
\hline BAHRAIN TELECOMMUNICATION COMPANY & Telecommunications & 2010 & $1,746,478$ & $1,339,399$ \\
\hline BAHRAIN TELECOMMUNICATION COMPANY & Telecommunications & 2011 & $1,743,272$ & $1,341,596$ \\
\hline BAHRAIN TELECOMMUNICATION COMPANY & Telecommunications & 2012 & $1,822,231$ & $1,364,168$ \\
\hline BAHRAIN TELECOMMUNICATION COMPANY & Telecommunications & 2013 & $2,756,011$ & $1,430,869$ \\
\hline BAHRAIN TELECOMMUNICATION COMPANY & Telecommunications & 2014 & $2,533,266$ & $1,411,317$ \\
\hline BAHRAIN TELECOMMUNICATION COMPANY & Telecommunications & 2015 & $2,650,164$ & $1,398,736$ \\
\hline BAHRAIN TELECOMMUNICATION COMPANY & Telecommunications & 2016 & $2,505,439$ & $1,307,337$ \\
\hline BAHRAIN TELECOMMUNICATION COMPANY & Telecommunications & 2017 & $2,466,934$ & $1,221,913$ \\
\hline BAHRAIN TELECOMMUNICATION COMPANY & Telecommunications & 2018 & $2,413,693$ & $1,230,815$ \\
\hline BAHRAIN TELECOMMUNICATION COMPANY & Telecommunications & 2019 & $2,626,651$ & $1,358,135$ \\
\hline BAHRAIN FLOUR MILLS COMPANY & Food \& Beverage & 2005 & 43,206 & 40,496 \\
\hline BAHRAIN FLOUR MILLS COMPANY & Food \& Beverage & 2006 & 40,707 & 39,665 \\
\hline BAHRAIN FLOUR MILLS COMPANY & Food \& Beverage & 2007 & 49,028 & 43,002 \\
\hline BAHRAIN FLOUR MILLS COMPANY & Food \& Beverage & 2008 & 65,917 & 41,488 \\
\hline BAHRAIN FLOUR MILLS COMPANY & Food \& Beverage & 2009 & 49,491 & 41,743 \\
\hline BAHRAIN FLOUR MILLS COMPANY & Food \& Beverage & 2010 & 54,869 & 42,912 \\
\hline BAHRAIN FLOUR MILLS COMPANY & Food \& Beverage & 2011 & 55,120 & 44,176 \\
\hline BAHRAIN FLOUR MILLS COMPANY & Food \& Beverage & 2012 & 51,876 & 46,505 \\
\hline
\end{tabular}




\begin{tabular}{|c|c|c|c|c|}
\hline Company & Industry & Year & Total Assets (\$ million) & Total Shareholders' Equity (\$ million) \\
\hline BAHRAIN FLOUR MILLS COMPANY & Food \& Beverage & 2013 & 61,994 & 49,137 \\
\hline BAHRAIN FLOUR MILLS COMPANY & Food \& Beverage & 2014 & 66,799 & 49,733 \\
\hline BAHRAIN FLOUR MILLS COMPANY & Food \& Beverage & 2015 & 63,654 & 49,086 \\
\hline BAHRAIN FLOUR MILLS COMPANY & Food \& Beverage & 2016 & 60,192 & 49,050 \\
\hline BAHRAIN FLOUR MILLS COMPANY & Food \& Beverage & 2017 & 58,231 & 48,431 \\
\hline BAHRAIN FLOUR MILLS COMPANY & Food \& Beverage & 2018 & 65,287 & 50,227 \\
\hline BAHRAIN FLOUR MILLS COMPANY & Food \& Beverage & 2019 & 68,749 & 53,087 \\
\hline DELMON POULTRY COMPANY & Food \& Beverage & 2005 & 33,999 & 32,748 \\
\hline DELMON POULTRY COMPANY & Food \& Beverage & 2006 & 35,257 & 33,701 \\
\hline DELMON POULTRY COMPANY & Food \& Beverage & 2007 & 37,652 & 35,806 \\
\hline DELMON POULTRY COMPANY & Food \& Beverage & 2008 & 35,943 & 33,958 \\
\hline DELMON POULTRY COMPANY & Food \& Beverage & 2009 & 36,908 & 35,188 \\
\hline DELMON POULTRY COMPANY & Food \& Beverage & 2010 & 38,609 & 36,801 \\
\hline DELMON POULTRY COMPANY & Food \& Beverage & 2011 & 39,194 & 37,019 \\
\hline DELMON POULTRY COMPANY & Food \& Beverage & 2012 & 40,867 & 38,514 \\
\hline DELMON POULTRY COMPANY & Food \& Beverage & 2013 & 41,152 & 39,446 \\
\hline DELMON POULTRY COMPANY & Food \& Beverage & 2014 & 44,080 & 40,709 \\
\hline DELMON POULTRY COMPANY & Food \& Beverage & 2015 & 42,043 & 39,814 \\
\hline DELMON POULTRY COMPANY & Food \& Beverage & 2016 & 38,342 & 35,297 \\
\hline DELMON POULTRY COMPANY & Food \& Beverage & 2017 & 36,568 & 33,484 \\
\hline DELMON POULTRY COMPANY & Food \& Beverage & 2018 & 37,796 & 34,063 \\
\hline DELMON POULTRY COMPANY & Food \& Beverage & 2019 & 40,093 & 34,918 \\
\hline TRAFCO GROUP BSC & Food \& Beverage & 2005 & 75,078 & 48,516 \\
\hline TRAFCO GROUP BSC & Food \& Beverage & 2006 & 73,155 & 45,622 \\
\hline TRAFCO GROUP BSC & Food \& Beverage & 2007 & 88,694 & 50,530 \\
\hline TRAFCO GROUP BSC & Food \& Beverage & 2008 & 103,936 & 55,310 \\
\hline TRAFCO GROUP BSC & Food \& Beverage & 2009 & 102,896 & 52,910 \\
\hline TRAFCO GROUP BSC & Food \& Beverage & 2010 & 102,013 & 54,146 \\
\hline TRAFCO GROUP BSC & Food \& Beverage & 2011 & 106,984 & 55,669 \\
\hline TRAFCO GROUP BSC & Food \& Beverage & 2012 & 99,587 & 53,236 \\
\hline TRAFCO GROUP BSC & Food \& Beverage & 2013 & 104,874 & 59,508 \\
\hline TRAFCO GROUP BSC & Food \& Beverage & 2014 & 106,674 & 62,073 \\
\hline TRAFCO GROUP BSC & Food \& Beverage & 2015 & 101,386 & 63,618 \\
\hline TRAFCO GROUP BSC & Food \& Beverage & 2016 & 101,719 & 63,411 \\
\hline TRAFCO GROUP BSC & Food \& Beverage & 2017 & 105,351 & 73,037 \\
\hline TRAFCO GROUP BSC & Food \& Beverage & 2018 & 105,172 & 76,053 \\
\hline TRAFCO GROUP BSC & Food \& Beverage & 2019 & 120,045 & 78,746 \\
\hline BAHRAIN CAR PARK COMPANY & Retail & 2005 & 30,576 & 29,666 \\
\hline BAHRAIN CAR PARK COMPANY & Retail & 2006 & 32,798 & 31,704 \\
\hline BAHRAIN CAR PARK COMPANY & Retail & 2007 & 31,960 & 30,626 \\
\hline
\end{tabular}

Retail 
Table A1 (cont.). List of all Bahraini non-financial listed companies covered by the study

\begin{tabular}{|c|c|c|c|c|}
\hline Company & Industry & Year & Total Assets (\$ million) & Total Shareholders' Equity (\$ million) \\
\hline BAHRAIN CAR PARK COMPANY & Retail & 2008 & 32,928 & 31,672 \\
\hline BAHRAIN CAR PARK COMPANY & Retail & 2009 & 34,006 & 32,711 \\
\hline BAHRAIN CAR PARK COMPANY & Retail & 2010 & 33,852 & 32,378 \\
\hline BAHRAIN CAR PARK COMPANY & Retail & 2011 & 34,226 & 32,619 \\
\hline BAHRAIN CAR PARK COMPANY & Retail & 2012 & 34,247 & 33,015 \\
\hline BAHRAIN CAR PARK COMPANY & Retail & 2013 & 34,105 & 33,571 \\
\hline BAHRAIN CAR PARK COMPANY & Retail & 2014 & 33,719 & 32,932 \\
\hline BAHRAIN CAR PARK COMPANY & Retail & 2015 & 34,141 & 33,191 \\
\hline BAHRAIN CAR PARK COMPANY & Retail & 2016 & 35,461 & 34,273 \\
\hline BAHRAIN CAR PARK COMPANY & Retail & 2017 & 36,153 & 35,269 \\
\hline BAHRAIN CAR PARK COMPANY & Retail & 2018 & 53,362 & 51,886 \\
\hline BMMI BSC & Retail & 2005 & 118,817 & 81,869 \\
\hline BMMI BSC & Retail & 2006 & 129,400 & 92,920 \\
\hline BMMI BSC & Retail & 2007 & 154,332 & 106,438 \\
\hline BMMI BSC & Retail & 2008 & 165,516 & 106,861 \\
\hline BMMI BSC & Retail & 2009 & 153,213 & 118,386 \\
\hline BMMI BSC & Retail & 2010 & 162,225 & 126,562 \\
\hline BMMI BSC & Retail & 2011 & 167,682 & 126,234 \\
\hline BMMI BSC & Retail & 2012 & 174,172 & 132,172 \\
\hline BMMI BSC & Retail & 2013 & 201,159 & 142,252 \\
\hline BMMI BSC & Retail & 2014 & 216,139 & 158,476 \\
\hline BMMI BSC & Retail & 2015 & 214,093 & 162,406 \\
\hline BMMI BSC & Retail & 2016 & 292,081 & 166,932 \\
\hline BMMI BSC & Retail & 2017 & 301,281 & 185,030 \\
\hline BMMI BSC & Retail & 2018 & 295,176 & 183,918 \\
\hline BMMI BSC & Retail & 2019 & 313,468 & 188,669 \\
\hline BAHRAIN DUTY FREE COMPANY & Retail & 2005 & 67,625 & 51,587 \\
\hline BAHRAIN DUTY FREE COMPANY & Retail & 2006 & 73,666 & 55,660 \\
\hline BAHRAIN DUTY FREE COMPANY & Retail & 2007 & 90,451 & 66,268 \\
\hline BAHRAIN DUTY FREE COMPANY & Retail & 2008 & 93,887 & 74,950 \\
\hline BAHRAIN DUTY FREE COMPANY & Retail & 2009 & 103,647 & 81,986 \\
\hline BAHRAIN DUTY FREE COMPANY & Retail & 2010 & 111,676 & 92,280 \\
\hline BAHRAIN DUTY FREE COMPANY & Retail & 2011 & 111,135 & 93,702 \\
\hline BAHRAIN DUTY FREE COMPANY & Retail & 2012 & 118,485 & 99,429 \\
\hline BAHRAIN DUTY FREE COMPANY & Retail & 2013 & 130,708 & 110,076 \\
\hline BAHRAIN DUTY FREE COMPANY & Retail & 2014 & 140,288 & 118,403 \\
\hline BAHRAIN DUTY FREE COMPANY & Retail & 2015 & 144,558 & 127,815 \\
\hline BAHRAIN DUTY FREE COMPANY & Retail & 2016 & 151,273 & 134,673 \\
\hline BAHRAIN DUTY FREE COMPANY & Retail & 2017 & 150,124 & 132,146 \\
\hline BAHRAIN DUTY FREE COMPANY & Retail & 2018 & 156,426 & 135,577 \\
\hline
\end{tabular}




Company

BAHRAIN SHIP REPAIRING AND ENGINEERING COMPANY BAHRAIN SHIP REPAIRING AND ENGINEERING COMPANY BAHRAIN SHIP REPAIRING AND ENGINEERING COMPANY BAHRAIN SHIP REPAIRING AND ENGINEERING COMPANY BAHRAIN SHIP REPAIRING AND ENGINEERING COMPANY BAHRAIN SHIP REPAIRING AND ENGINEERING COMPANY BAHRAIN SHIP REPAIRING AND ENGINEERING COMPANY BAHRAIN SHIP REPAIRING AND ENGINEERING COMPANY BAHRAIN SHIP REPAIRING AND ENGINEERING COMPANY BAHRAIN SHIP REPAIRING AND ENGINEERING COMPANY BAHRAIN SHIP REPAIRING AND ENGINEERING COMPANY BAHRAIN SHIP REPAIRING AND ENGINEERING COMPANY BAHRAIN SHIP REPAIRING AND ENGINEERING COMPANY BAHRAIN SHIP REPAIRING AND ENGINEERING COMPANY BAHRAIN SHIP REPAIRING AND ENGINEERING COMPANY ALUMINIUM BAHRAIN BSC ALUMINIUM BAHRAIN BSC ALUMINIUM BAHRAIN BSC ALUMINIUM BAHRAIN BSC ALUMINIUM BAHRAIN BSC ALUMINIUM BAHRAIN BSC ALUMINIUM BAHRAIN BSC ALUMINIUM BAHRAIN BSC ALUMINIUM BAHRAIN BSC ALUMINIUM BAHRAIN BSC ZAIN BAHRAIN BSC

ZAIN BAHRAIN BSC

ZAIN BAHRAIN BSC

ZAIN BAHRAIN BSC

ZAIN BAHRAIN BSC

ZAIN BAHRAIN BSC

BAHRAIN CINEMA COMPANY

BAHRAIN CINEMA COMPANY

BAHRAIN CINEMA COMPANY

BAHRAIN CINEMA COMPANY

BAHRAIN CINEMA COMPANY

BAHRAIN CINEMA COMPANY

BAHRAIN CINEMA COMPANY

BAHRAIN CINEMA COMPANY

Industry

Retail

Ind. Goods \& Services

Ind. Goods \& Services

Ind. Goods \& Services

Ind. Goods \& Services

Ind. Goods \& Services

Ind. Goods \& Services

Ind. Goods \& Services

Ind. Goods \& Services

Ind. Goods \& Services

Ind. Goods \& Services

Ind Goods \& Services

Ind. Goods \& Services

Ind. Goods \& Services

Ind. Goods \& Services

Ind. Goods \& Services

Basic Resources

Basic Resources

Basic Resources

Basic Resources

Basic Resources

Basic Resources

Basic Resources

Basic Resources

Basic Resources

Basic Resources

Telecommunications

Telecommunications

Telecommunications

Telecommunications

Telecommunications

Telecommunications

Travel \& Leisure

Travel \& Leisure

Travel \& Leisure

Travel \& Leisure

Travel \& Leisure

Travel \& Leisure

Travel \& Leisure
Total Assets (\$ million)

Total Shareholders' Equity (\$ million)

Year

Total Assets (\$ million)

\begin{tabular}{c|c}
163,987 & 139,995 \\
\hline 40,770 & 36,985
\end{tabular}

\begin{tabular}{l|l}
40,770 & 36,985
\end{tabular}

$40,819+\ldots \ldots \ldots \ldots \ldots \ldots \ldots$

$44,300+\cdots \cdots \cdots$

$48,980 \quad 44,258$

\begin{tabular}{l|l}
52,210 & 47,239
\end{tabular}

$60,027 \quad 54,773$

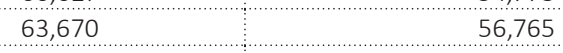

$63,092 \quad-\quad 56,678$

$66,021 \quad 59,932$

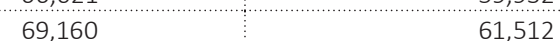

$71,604 \quad 62,839$

$\begin{array}{l:c}74,469 & 66,637\end{array}$

\begin{tabular}{l|r}
83,037 & 74,241
\end{tabular}

$94,093 \quad 81,434$

$3,518,554 \quad 1,853,13$

$3,460,583 \quad 2,145,093$

$3,259,799 \quad 2,200,335$

3,125,479

\begin{tabular}{l:c}
$3,125,479$ & $2,303,68$ \\
\hline $3,081,936$ & $2,435,378$
\end{tabular}

$3,081,936$
$3,133,416$
$3,113,347$

$3,113,347 \quad 2,620,974$

$4,460,794 \quad 2,784,111$

$5,843,169 \quad 2 \cdots \cdots \cdots \cdots \cdots \cdots \cdots \cdots \cdots \cdots \cdots \cdots \cdots \cdots \cdots \cdots$

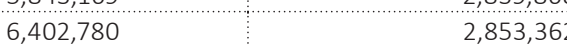

$296,503 \quad 157,371$

$311,227 \quad 166,788$

$313,210 \quad 173,355$

269,635 ..................................... 177,540

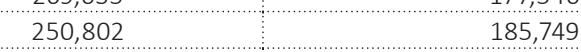

\begin{tabular}{l|l}
314,124 & 191,167
\end{tabular}

\begin{tabular}{l|l}
72,098 & 66,357
\end{tabular}

$79,975 \quad 76,253$

$99,227 \quad 93,772$

$99,777 \quad 85,654$

$90,549 \quad 84,315$

$98,645 \quad 91,489$

$91,799 \quad-\quad 85,854$

\begin{tabular}{r|r}
97,293 & 89,680 \\
\hline
\end{tabular}


Table A1 (cont.). List of all Bahraini non-financial listed companies covered by the study

\begin{tabular}{|c|c|c|c|c|}
\hline Company & Industry & Year & Total Assets (\$ million) & Total Shareholders' Equity (\$ million) \\
\hline BAHRAIN CINEMA COMPANY & Travel \& Leisure & 2013 & 110,339 & 99,392 \\
\hline BAHRAIN CINEMA COMPANY & Travel \& Leisure & 2014 & 121,357 & 112,140 \\
\hline BAHRAIN CINEMA COMPANY & Travel \& Leisure & 2015 & 124,933 & 110,872 \\
\hline BAHRAIN CINEMA COMPANY & Travel \& Leisure & 2016 & 125,171 & 114,222 \\
\hline BAHRAIN CINEMA COMPANY & Travel \& Leisure & 2017 & 219,307 & 197,244 \\
\hline BAHRAIN CINEMA COMPANY & Travel \& Leisure & 2018 & 245,506 & 197,550 \\
\hline BAHRAIN CINEMA COMPANY & Travel \& Leisure & 2019 & 244,442 & 196,780 \\
\hline BAHRAIN FAMILY LEISURE COMPANY & Travel \& Leisure & 2005 & 12,869 & 12,071 \\
\hline BAHRAIN FAMILY LEISURE COMPANY & Travel \& Leisure & 2006 & 11,574 & 10,368 \\
\hline BAHRAIN FAMILY LEISURE COMPANY & Travel \& Leisure & 2007 & 12,942 & 12,112 \\
\hline BAHRAIN FAMILY LEISURE COMPANY & Travel \& Leisure & 2008 & 13,924 & 12,963 \\
\hline BAHRAIN FAMILY LEISURE COMPANY & Travel \& Leisure & 2009 & 11,985 & 10,854 \\
\hline BAHRAIN FAMILY LEISURE COMPANY & Travel \& Leisure & 2010 & 13,348 & 12,214 \\
\hline BAHRAIN FAMILY LEISURE COMPANY & Travel \& Leisure & 2011 & 12,722 & 11,357 \\
\hline BAHRAIN FAMILY LEISURE COMPANY & Travel \& Leisure & 2012 & 13,694 & 12,423 \\
\hline BAHRAIN FAMILY LEISURE COMPANY & Travel \& Leisure & 2013 & 15,780 & 14,802 \\
\hline BAHRAIN FAMILY LEISURE COMPANY & Travel \& Leisure & 2014 & 21,101 & 20,048 \\
\hline BAHRAIN FAMILY LEISURE COMPANY & Travel \& Leisure & 2015 & 18,241 & 17,204 \\
\hline BAHRAIN FAMILY LEISURE COMPANY & Travel \& Leisure & 2016 & 18,760 & 17,634 \\
\hline BAHRAIN FAMILY LEISURE COMPANY & Travel \& Leisure & 2017 & 21,217 & 19,565 \\
\hline BAHRAIN FAMILY LEISURE COMPANY & Travel \& Leisure & 2018 & 17,523 & 15,865 \\
\hline BAHRAIN FAMILY LEISURE COMPANY & Travel \& Leisure & 2019 & 15,201 & 11,632 \\
\hline GULF HOTELS GROUP & Travel \& Leisure & 2005 & 82,307 & 72,359 \\
\hline GULF HOTELS GROUP & Travel \& Leisure & 2006 & 92,328 & 80,126 \\
\hline GULF HOTELS GROUP & Travel \& Leisure & 2007 & 104,325 & 89,518 \\
\hline GULF HOTELS GROUP & Travel \& Leisure & 2008 & 119,470 & 105,681 \\
\hline GULF HOTELS GROUP & Travel \& Leisure & 2009 & 136,398 & 119,076 \\
\hline GULF HOTELS GROUP & Travel \& Leisure & 2010 & 154,528 & 132,808 \\
\hline GULF HOTELS GROUP & Travel \& Leisure & $2011 \ldots$ & 160,199 & 141,984 \\
\hline GULF HOTELS GROUP & Travel \& Leisure & 2012 & 176,411 & 156,392 \\
\hline GULF HOTELS GROUP & Travel \& Leisure & 2013 & 193,216 & 170,510 \\
\hline GULF HOTELS GROUP & Travel \& Leisure & 2014 & 208,973 & 184,312 \\
\hline GULF HOTELS GROUP & Travel \& Leisure & 2015 & 218,629 & 191,356 \\
\hline GULF HOTELS GROUP & Travel \& Leisure & 2016 & 309,198 & 275,945 \\
\hline GULF HOTELS GROUP & Travel \& Leisure & 2017 & 320,021 & 295,684 \\
\hline GULF HOTELS GROUP & Travel \& Leisure & 2018 & 374,721 & 300,753 \\
\hline GULF HOTELS GROUP & Travel \& Leisure & 2019 & 361,712 & 304,177 \\
\hline
\end{tabular}

